[Agr. Biol. Chem., Vol. 31, No. 4, p. 422 427, 1967]

\title{
Inhibition of Respiration of Yeast by Photosynthesis Inhibiting Herbicides
}

\author{
By Yorinao Inoue, Kôzô Ishizuka and Shingo Mitsui \\ Department of Science in Agricultural Chemicals \\ The Institute of Physical and Chemical Research \\ Received September 10, 1966
}

\begin{abstract}
In order to elucidate the mode of action of some herbicides, effect of several anilide type herbicides on the respiration of yeast cells was studied. The results obtained were as follows: 1) DCPA (3,4-dichloropropionanilide) and DCMU (3-(3,4-dichlorophenyl)-1,1dimethylurea), the powerful inhibitors of the Hill reaction in photosynthesis, inhibited the oxygen uptake of yeast cells at low concentrations. 2) DCPA and DCMU inhibited the enzymic reduction of cytochrome-c by the yeast cell-free preparation, but not the reduction of dye. 3) The oxidation of cytochrome-b was inhibited in the yeast cells treated with DCPA or DGMU.
\end{abstract}

\section{INTRODUCTION}

Anilide type herbicides such as acylanilides, phenylureas and phenylcarbamates are the most potent specific inhibitors of photosynthesis. " Wessels and Van der Veen ${ }^{2 !}$ first discovered that CMU (3-(4-chlorophenyl)-1,1dimethylurea) and other substituted phenylureas were powerful inhibitors of the Hill reaction. The inhibitory effect of these substances on photoreactions has subsequently been studied by Bishop, ${ }^{31}$ Jagendorf, ${ }^{4,5)}$ Good $^{6,71}$ and others. ${ }^{8 \sim 121}$

Herbicidal activity and mode of action of these substances have been discussed in series

I) M. Losada and D. I. Arnon, "Metabolic Inhibitors" vol. 2 Academic Press, 1963, p. 571.

2) J.C. S. Wessels and R. Van der Veen, Biochem. et Biophys. Acta, 19, 548 (1965).

3) N. I. Bishop, ibid., 27, 205 (1958).

4) A. T. Jagendorf and M. Avron, Arch. Biochem. B.ophys., 80, 246 (1959).

5) A. T. Jagendorf and M. Margies, ibid., 90 $184(1960)$

6) N. E. Good, Plant Physiol., 36, 788 (1961).

7) S. Izawa and N. E. Good, Biochim. et Biophys. Acta, 102, 20 (1965).

8) P. B. Sweetser, C. W. Todd and R. T. Hersh, ibid., 51, 509 (1961). of studies by Good et al., ${ }^{6,14}$ Murashige et al., ${ }^{13)}$ on the other hand, have found that several photosynthesis inhibiting herbicides are toxic to non-photosynthetic tobacco callus tissue. Regarding the mechanism of selective toxicity of DCPA, we found that these substances not only inhibit the photosynthesis but also interfere with the respiration of plant root and are toxic to etiolated seedlings. Consequently the inhibitory effect of these substances on the respiration of yeast cells was investigated and the results indicate that acylanilides as well as phenylureas are fairly strong inhibitors of cytochrome system of the respiratory chain.

9) L. M. N. Duysens and J. Amesz, ibid., 64, 243 (1962).

10) J. Amesz and L. M. N. Duysens, ibid., 64, 261 (1962).

11) M. Nishimura, H. Sakurai and A. Takamiya, ibid., 79, 241 (1964).

12) G. Zweig, I. Tamas and E. Greenberg, ibid., 66, 196 (1963).

13) L.S. Jordan, T. Murashige, J. D. Mann and P. B. Day, Weeds, 14, 134 (1966).

14) N. E. Good, "World Review of Pest Control Spring 1962, 1." Part 1, p. 19. 


\section{MATERIAL AND METHODS}

One liter of the synthetic culture medium for growth test contained glucose $10 \mathrm{~g}, \mathrm{NH}_{4} \mathrm{Cl} 1.1 \mathrm{~g}$, $\mathrm{CaCl}_{2} \cdot 2 \mathrm{H}_{2} \mathrm{O} 0.07 \mathrm{~g}, \mathrm{KCl} 0.6 \mathrm{~g}, \mathrm{MgCl}_{2} \cdot 6 \mathrm{H}_{2} \mathrm{O} 0.4 \mathrm{~g}$; $\mathrm{Na}_{2} \mathrm{HPO}_{4} 2.5 \mathrm{~g}$, citric acid $1.8 \mathrm{~g}, \mathrm{Na}_{2} \mathrm{SO}_{4} \cdot 10 \mathrm{H}_{2} \mathrm{O} 0.6 \mathrm{~g}$, inositol $2 \mathrm{mg}$, thiamine- $\mathrm{HCl} 400 \mu \mathrm{g}$, pyridoxine- $\mathrm{HCl}$ $400 \mu \mathrm{g}$, biotin $2 \mu \mathrm{g}$, and pantothenic acid $200 \mu \mathrm{g}$. Precultured cells of Bakers' yeast (Saccharomyces cereyisiae) were inoculated into synthetic media containing each of various acylanilides and cultured under shaking at $30^{\circ} \mathrm{C}$. Growth of yeast cells was evaluated from the absorbance at $660 \mathrm{~m} \mu$ periodically in the growth test. Acylanilides were added to the media as ethanol solution; the final concentration of ethanol being adjusted at 4 vol. $\%$ in every experiment. Cells for oxygen uptake and cell-free experiments were cultured alike in synthetic media at $30^{\circ} \mathrm{C}$ under shaking. Cells at the post logarithmic phase and stationary phase were used for the oxygen consumption and for the preparation of particle fraction respectively. Warburg manometric method was used to determine the rate of oxygen uptake.

Cell-free particle fraction was prepared by the procedure as follows; $2 \mathrm{~g}$ (wet weight) of harvested cells was suspended in $25 \mathrm{ml}$ of cold buffered solution containing $1 \% \mathrm{NaCl}, 5 \mathrm{~mm}$ EDTA, $20 \mathrm{~mm}$ Tris ( $\mathrm{pH} \mathrm{8),}$ and homogenized for $50 \mathrm{sec}$. with glass beeds in a Cell Homogenizer (Germany). After removal of beeds, the juice was centrifuged to separate the debris and living cells. The supernatant was cenntrifuged for $10 \mathrm{~min}$. at $10^{4} \mathrm{~g}$ to get particle fraction. After 2 times washing, the precipitate was suspended in buffered solution containing $1 \% \mathrm{NaCl}, 1 \mathrm{mM}$ EDTA, $10 \mathrm{mM}$ phosphate ( $\mathrm{pH} 6.9$ ).

Spectrophotometric technique was used throughout for the studies of electron transport system. Rate of oxido-reduction of cytochrome-c or dye was measured from the change in absorbance at $550 \mathrm{~m} \mu$ automatically by Hitachi QPD-33 recorder equipped with Hitachi-ParkinElmer 139 UV-VIS Spectrophotometer. Absorption spectrum of the yeast cell suspension was obtained by opal glass method using Cary model 14 .

Cytochrome-c was obtained from Sigma Chem. Co., Ltd., Antimycin A from Kyowa Hakko Kogyo Co., Ltd., and acylanilides from Hodogaya Kagaku Co., Ltd. Reduced form of cytochrome-c was prepared by reduction of this product with hydrogen, palladium-asbestos serving as a catalyst.

\section{RESULTS}

Inhibition of growth and respitation of yeast cell by several acylanilides.

Table I shows the effect of several acylanilides on the growth of yeast cells and on the oxygen uytake of yeast cell suspension. DCPA and PCPA (4-chloropropionanilide) were found to be fairly strong inhibitors on the cell growth among monochloro and dichloro groups. However, 3-chloro, 2-chloro or 2,3-dichloro 2,4-dichloro derivatives were found to be nearly inactive. This result agrees with those obtained from the Hill reaction inhibition experiment ${ }^{6,15}$ and from the bacteriostatic test of substituted phenylureas. ${ }^{161}$

TABLE I. EFFECT OF VARIOUS ACYLANILIDES ON CELL GROWTH AND ON OXYGEN UPTAKE OF BAKER'S YEAST

$\begin{array}{lcc}\text { Chemical } & \begin{array}{c}\text { Cell } \\ \text { Growth } \\ 100 \%\end{array} & \begin{array}{c}\text { Oxygen } \\ \text { Uptake Rate }\end{array} \\ \text { control } & 100 \% \\ \text { phenyl-PA (propionanilide) } & 100 & 88 \\ \text { 2-chloro-PA } & 95 & 93 \\ \text { 3-chloro-PA } & 91 & 89 \\ \text { 4-chloro-PA } & 33 & 33 \\ \text { 2,3-dichloro-PA } & 101 & 92 \\ \text { 2,5-dichloro-PA } & 100 & 91 \\ \text { 3,4-dichloro-PA } & 5.8 & 9.5 \\ \text { 2,4,6-trichloro-PA } & 102 & 85 \\ \text { 2,4,5-trichloro } & 101 & 87 \\ \text { pentachloro-PA } & 100 & 91 \\ \text { 3-chloroaniline } & 99 & 90 \\ \text { 4-chloroaniline } & 100 & 89 \\ \text { 3,4-dichloroaniline } & 6.3 & 80\end{array}$

Twenty-five $\mathrm{ml}$ of synthetic medium was inoculated with $2 \times 10^{2}$ cells. Inhibitors were added to the medium as ethanol solution before sterilization. Turbidity of the medium was determined after $30 \mathrm{hr}$. culture. The turbidity and the rate of oxygen uptake of the control experiment were $0.950\left(\mathrm{OD}_{660 \mathrm{~m} \mu}\right)$ and $107 \mu 10_{2} / 30 \mathrm{~min}$., respectively. The reaction mixture of oxygen uptake experiment, $3.0 \mathrm{ml}$ in each vessel, contained $133 \mu \mathrm{M}$ potassium phosphate (pH 6.9); acylanilide $0.6 \mathrm{mg}$. and approximately $10 \mathrm{mg}$ of wet yeast cells.

15) C. Hansh and E. Deuth, Bicchim. et Biophys. Acta, 112, 381 (1966).

16) D. J. Beaver, D. P. Roman and P. J. Stoffel, J. Am. Chem. Soc., 79, 1236 (1957). 
Though anilines were less effective than the corresponding anilides, 3,4-dichloroaniline (DCA) showed an inhibition on the cell growth. In the respiration inhibition experiment, it was found that only DCPA and PCPA were effective inhibitors, much the same as shown in the inhibition experiment on the cell growth. Three aniline derivatives showed slight inhibition on the oxygen uptake, although DCA was inhibitory to the yeast cell growth.

Inhibitory activities of several acylanilides and a phenylurea on oxygen uptake were determined at varying concentrations. The titration curve of inhibition illustrated in Fig. 1 indicates that the phenylurea as well as acylanilides inhibit oxygen uptake at low concentrations; DCMU is the strongest, DCPA and PCPA follow. As to the effect of DCPA

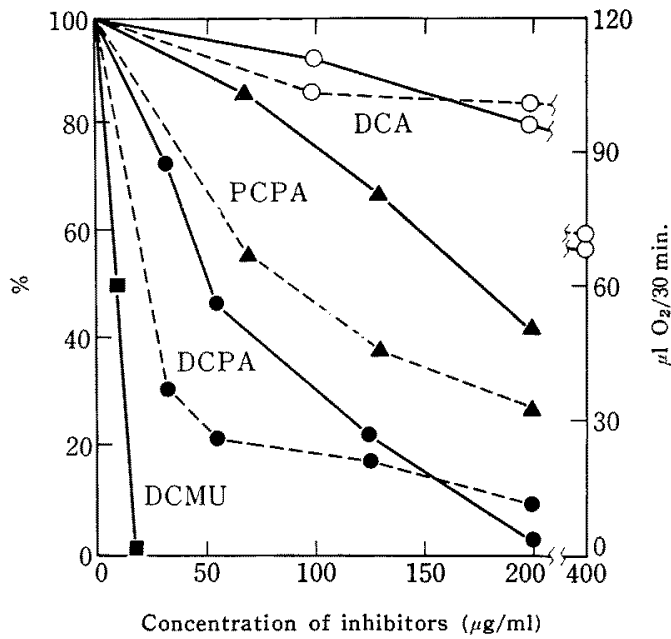

FIG. 1. Effect of Varying Concentrations of DCPA, PCPA, DCA and DCMU on Oxygen Uptake by Cell Suspension and Cell-free system.

Cell suspension experiment were performd as described in Table 1. Sixty $\mu \mathrm{M}$ of Na-succinate was added to the reaction mixture as substrate in cell-free experiment. Each vessel contained approximately $25 \mu \mathrm{g}$ of protein-N as enzyme preparation.

- cell suspension, - - cell-free system. $I_{50}$ were as follows; DCPA $8.3 \times 10^{-5} \mathrm{M}$, DCMU $1.8 \times$ $10^{-5} \mathrm{M}$, PCPA $3.2 \times 10^{-4} \mathrm{M}$, DCA $>10^{-3} \mathrm{M}$. and PCPA, a little higher concentrations were required to inhibit the oxygen uptake of yeast cell suspension system compared to the cellfree system. DCA, on the other hand, shows a slight inhibition in both systems. This result agrees with the order of potency observed in the Hill reaction inhibition experiment.

\section{Inhibition of electron transport system.}

Inhibitory effect of these acylanilides on the electron transport system of yeast cell-free preparation is demonstrated in Fig. 2. When cytochrome-c is employed as the terminal electron acceptor during succinate oxidation by yeast cell-free preparation, it was observed that some acylanilides inhibit the reduction of cytochrome-c. Among several herbicides described in Table I, DCPA and DCMU were the most effective inhibitors and the others were nearly inactive. Reduction of cytochrome-c was inhibited more than 90\% in the presence of either $75 \mu \mathrm{g} / \mathrm{ml}$ of DCPA

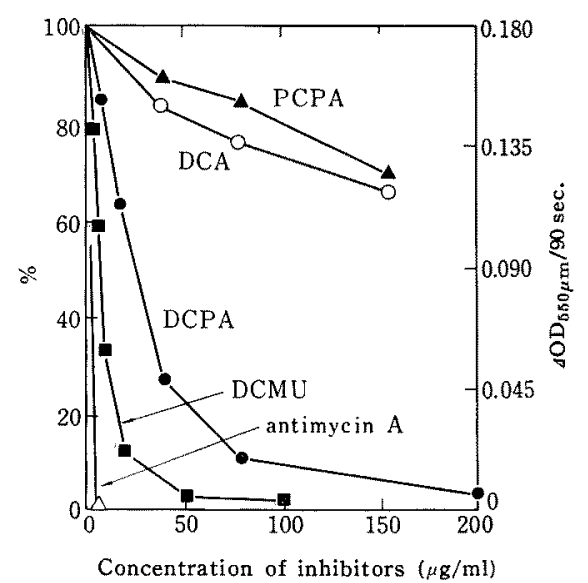

FIG. 2. Effect of Varying Concentrations of Inhibitors on Succinic-cytochrome-c Reduction System.

The reaction mixture, $3.0 \mathrm{ml}$ in each cell, contained: $146 \mu \mathrm{M}$ potassium phosphate ( $\mathrm{pH} 7.0$ ); $20 \mu \mathrm{M}$ neutralized $\mathrm{KCN} ; 0.52 \mu \mathrm{M}$ cytochrome-c; $60 \mu \mathrm{M} \mathrm{Na}$ succinate; enzyme preparation.

$\mathrm{I}_{50}$ were as follows; DCPA $1.1 \times 10^{-4} \mathrm{M} ; \mathrm{DCMU}$ $2.3 \times 10^{-5} \mathrm{M}$; DCA $>10^{-3} \mathrm{M}$, PCPA $>10^{-8} \mathrm{M}$. Other derivatives were nearly inactive at $200 \mu \mathrm{g} / \mathrm{ml}$. 


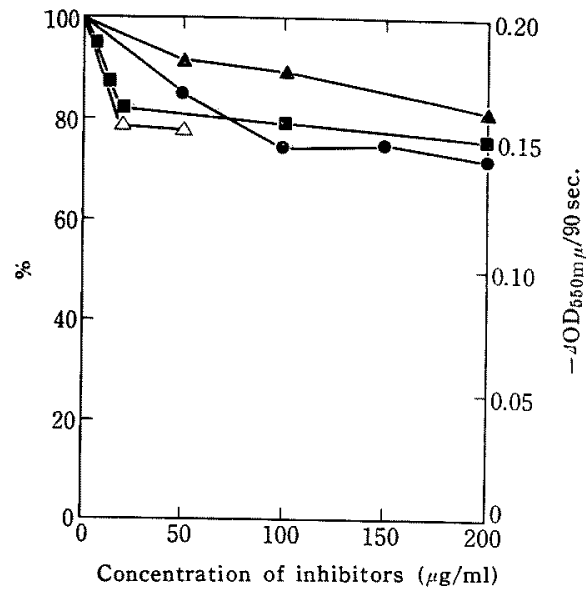

FIG. 3. Effect of Varying concentration of Inhibitors on Succinic-DPIP Reduction System.

Composition of reaction mixture was the same as described in Fig. 2, except cytochrome-c. $67 \mu \mathrm{M}$ of DPIP was added in place of cytochrome-c. $T_{50}$ of all inhibitors used was more than $10^{-3} \mathrm{M}$.
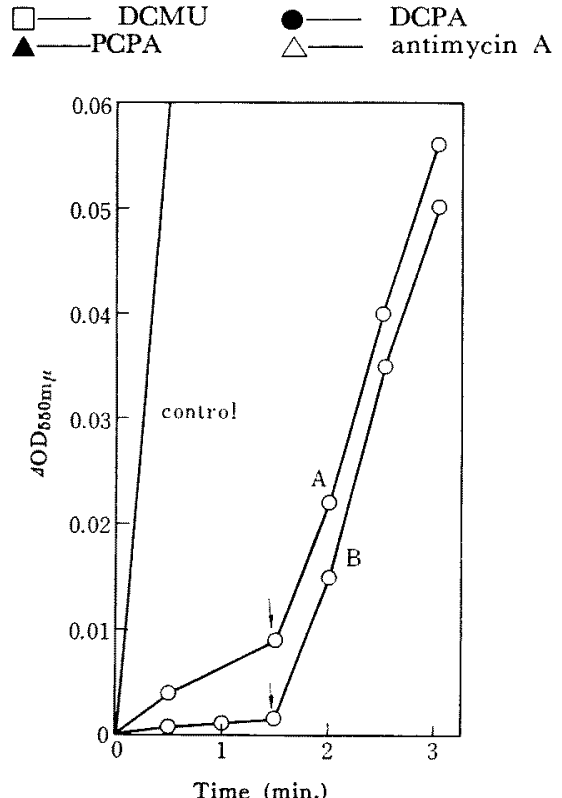

FIG. 4. Restoration of Inhibition of Cytochrome-c Reduction by the Addition of Dye.

A drop of $1 \mathrm{mM}$ DPIP solution was added at $1.5 \mathrm{~min}$.

A: inhibited by DCMU; B: inhibited by antimycin A.

The experiment conditions were the same as described in Fig. 2. or $25 \mu \mathrm{g} / \mathrm{ml}$ of DGMU and the concentration of DCPA and DCMU to cause the $50 \%$ inhibition was lower than that causing the $50 \%$ inhibition of respiration. Antimycin A also inhibited this reaction perfectly at a low concentration.

On the other hand, when DPIP (2,6-dichlorophenol-indophenol) was employed as the terminal electron accepter in the identical experiment, those anilides showed only slight inhibition on the reduction of dye. Fig. 3 shows the titration curve of the inhibition at varying concentrations of the herbicides which were found to be inhibitory in the cytochrome-c reduction system. Antimycin A as

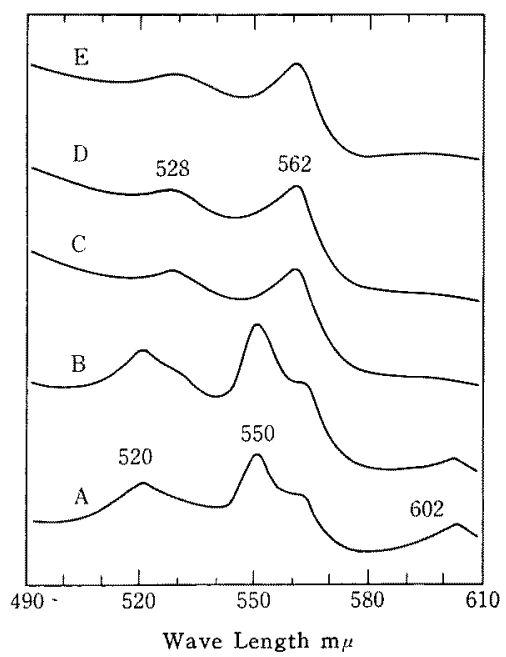

FIG. 5. Absorption Spectra of Yeast Cell Suspension Treated with DCPA or DCMU.

The absorption spectra were obtained by opal glass method, distilled water reference. The cell suspension was treated with each reagent at $30^{\circ} \mathrm{C}$ for $1 \mathrm{hr}$. under shaking.

A: treated with dithionite, B: with $\mathrm{KCN}, \mathrm{C}$ : with DCPA, D: with DCMU and E: with antimycin A. $602 \mathrm{~m} \mu, 550 \mathrm{~m} \mu$ and $520 \mathrm{~m} \mu$ peaks shown in $\mathrm{A}$ and $\mathrm{B}$ correspond to the $\alpha$-band of cyt-a, $\alpha$-band of cyt-c and $\beta$-band of cyt-c, respectively. $560 \mathrm{~m} \mu$ and $530 \mathrm{~m} \mu$ sholders may correspond to the $\alpha$-band and $\beta$-band of cyt-b. $562 \mathrm{~m} \mu$ and $528 \mathrm{~m} \mu$ peaks found in $\mathrm{C}, \mathrm{D}, \mathrm{E}$, are the $\alpha$-band and $\beta$-band of cyt-b which were found as sholders in $\mathrm{A}$ and $\mathrm{B}$. 
well as those herbicides was less effective at the high concentration in this system compared with its effect in the cytochrome-c reduction system. When a drop of DPIP solution was added into the phenylurea or antimycin A inhibited cytochrome-c reduction system, a sharp restoration of the inhibition occurred as illustrated in Fig. 4. These data suggest that the locus of the inhibition by these herbicides is close to the cytochrome-c reduction. This result is supported by the spectrum analysis of yeast cell suspension treated with DCPA or DCMU, as shown in Fig. 5. Comparison of the spectrum of DCPA or DCMU treated cells with that of dithionite or $\mathrm{KCN}$ treated cells showed that $602 \mathrm{~m} \mu, 550 \mathrm{~m} \mu$ and $520 \mathrm{~m} \mu$ peaks disappeared, $562 \mathrm{~m} \mu$ and $528 \mathrm{~m} \mu$ peaks became marked by the treatment with DCPA or DCMU. The same change in spectrum occurred by treating the cell with antimycin $\mathrm{A}$, indicating that only cy tochrome-b remained reduced, though cytochrome-c and cytochrome-a were oxidized in the cells treated with the herbicides. These data suggested that DCPA and DCMU exert the inhibition of respiration by inhibiting the electron flow from cytochrome-b to cytochrome-c in yeast cell.

The effect of these herbicides on the enzymic oxidation of chemically reduced cytochrome-c were also studied. However, as shown in Table II, they were nearly inactive in this reaction.
TABLE II. EFFECT OF THE HERBICIDES ON CyTOCHROME OXIDASE

Treatment Control DCPA DCMU PCPM DCA

$\begin{array}{llllll}\text { Decrease in } & 0.24 & 0.22 & 0.19 & 0.20 & 0.26\end{array}$

Reaction mixture, $3.0 \mathrm{ml}$ in each cell, contained $146 \mu \mathrm{M}$ of potassium phosphate $(\mathrm{pH} 7.0) ; 0.4 \mu \mathrm{M}$ of reduced cytochrome-c; $300 \mu \mathrm{g}$ of inhibitor and enzyme preparation.

\section{DISCUSSION}

Substituted phenylureas and acylanilides are the most commonly employed inhibitors of the photosynthensis. They were shown to be inhibitors of the Hill reaction, ${ }^{2)}$ to inhibit photosynthesis but not photoreduction, ${ }^{3 \prime}$ and to inhibit the electron transfer and associated phosphorylation." From the observation that the inhibition of NADP reduction by phenylureas is relieved by the addition of ascorbate and DPIP, it has been thought that the site of action of these herbicides is located rather in the oxygen evolution system than in cytochrome system that connects the two photoreactions in chloroplasts. ${ }^{17}$

The experimental results indicated that acylanilides as well as phenylurea inhibit the electron transport in the yeast cell-free preparation; the site of action seems to be placed between cytochrome-b and cytochrome-c. It seems to be difficult to connect the result of this investigation with the knowledges ob-

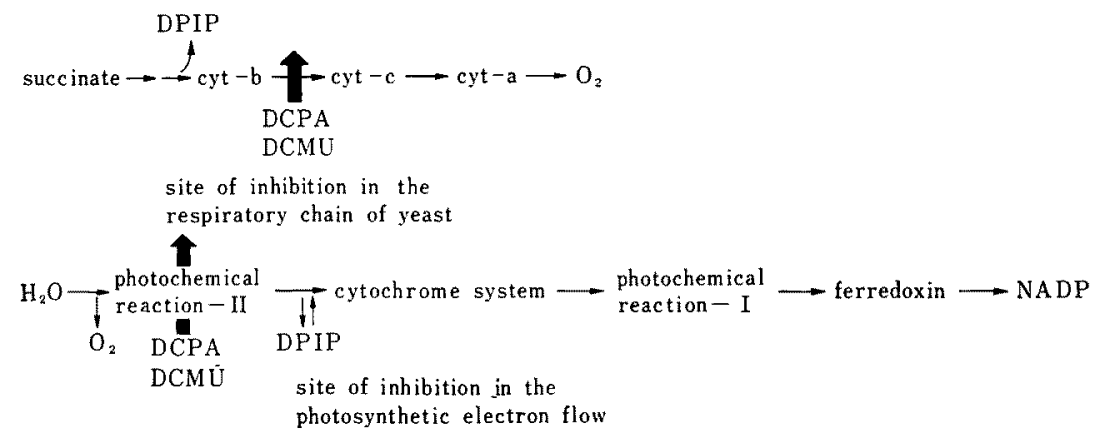

17) L. P. Vernon and W.S. Zaugg, J. Biol. Chem.. 235, 2728 (1960). 
tained from the inhibition experiments by the herbicides in chloroplasts. However, considering that the intermediate electron transfer system which connects the two photochemical steps in chloroplasts is identical in its fundamental construction to that of respiratory one,

18) L.M. N. Duysens, J. Amesz and B. M. Kamp, Nature, 190, $510(1960)$.

19) P. R. Levine and R. M. Smillie, Proc. Natl. Acad. Sci. U.S., 48, 417 (1962). and so far as the exact site of interaction of artificial Hill reagents is not made clear, ${ }^{18 \sim 20}$ there might be a possibility that these herbicides inhibit the electron transport in the respiratory chain by the same manner as in the Hill reaction.

20) J.Amesz, Biochim. et Biophys. Acta, 79, 257 (1964). 